\title{
The future of Russian LNG on the world gas markets
}

\author{
Natalia Pyatkova ${ }^{1 *}$ \\ ${ }^{1}$ Melentiev Energy Systems Institute, 130 Lermontov str., Irkutsk, Russia
}

\begin{abstract}
The main purpose of the article is to analyze the situation on the world markets of liquefied natural gas (LNG) and Russia's ability to enter this market. This article continues the work carried out 15 years ago on possible ways of diversifying the forms and directions of Russian gas exports [1]. An analysis of the state of the LNG market for this period was made, prospects for the development of world trade in LNG and promising Russian projects were considered.
\end{abstract}

\section{The current state of the LNG markets}

In the 90 years of the last century, as a result of the use of the latest LNG technologies, the export of natural gas in liquefied form has significantly increased. Now this is a large-scale business, providing more than a quarter of international gas trade (Table 1). LNG technologies are increasingly competing the traditional for Russia gas exports using pipelines. In the long term future growth of production and consumption of liquefied natural gas is forecasted, and an increasing part of international gas trade will occur as LNG supplies. According to the available forecasts, the LNG trade in 2020 may amount to more than 450 billion $\mathrm{m} 3$, and by 2030 the deliveries can reach almost 700 billion $\mathrm{m} 3$ and will account for $45 \%$ of the world gas trade.

Table 1. The share of liquefied natural gas in world gas exports [2-5].

\begin{tabular}{|c|l|l|l|l|l|}
\hline & $2001 \Gamma$. & $2005 \Gamma$. & $2010 \Gamma$. & 2015 г. & 2016 г. \\
\hline World gas exports, bn. m ${ }^{3}$ & 554,2 & 721,4 & 975,2 & 1034,5 & 1084,1 \\
including pipeline gas & 411,2 & 532,6 & 677,6 & 709,1 & 737,5 \\
LNG & 143,0 & 188,8 & 297,6 & 325,5 & 346,6 \\
\hline $\begin{array}{c}\text { Share in total exports, \% } \\
\text { pipeline gas }\end{array}$ & 74,2 & 73,8 & 69,5 & 68,5 & 68,0 \\
LNG & 25,8 & 26,2 & 30,5 & 31,5 & 32,0 \\
\hline Russia, billion m & 126,9 & 151,3 & 199,9 & 207,5 & 204,8 \\
pipeline gas & 126,9 & 151,3 & 186,5 & 193,0 & 190,9 \\
LNG & - & - & 13,4 & 14,5 & 14,0 \\
The Russia share in total world exports, \% & & & & & \\
pipeline gas & 30,9 & 28,4 & 27,5 & 27,2 & 25,9 \\
LNG & - & & 4,5 & 4,3 & 4,0 \\
\hline
\end{tabular}

Compared with gas deliveries by pipeline, deliveries using LNG technologies have a number of important advantages:

- "mobility" of LNG - if necessary, it can be delivered from any liquefaction plant to any regasification terminal of any country. Manufacturers and buyers of liquefied natural gas are more free to choose a trading partner than those who focus only on pipeline gas;

- LNG technologies allow to promptly change volumes of production and gas supplies depending on market conditions, and gas transportation is not connected with transit through the territories of third countries and, consequently, there is the possibility of rapid response to fluctuations in demand. The opportunities for market trade in LNG contracts are particularly attractive for the largest importers, namely, the largest consumer of Russian gas, the European Union, which is reforming its gas market in this direction;

- LNG is the only possible technology for the organization of trans-oceanic transport, which is especially important for the countries of the Asia-Pacific region.

LNG technologies are become constantly cheaper (Figure 1). Unit capital costs for the construction of gas liquefaction plants, for example, decreased to \$250/ ton. Due to a significant increase in the carrying capacity

* Corresponding author: nata@isem.irk.ru 
of tankers, the cost of transporting LNG is also reduced. As a result, the cost of LNG at the location of major gas markets is approaching the cost of pipeline gas.

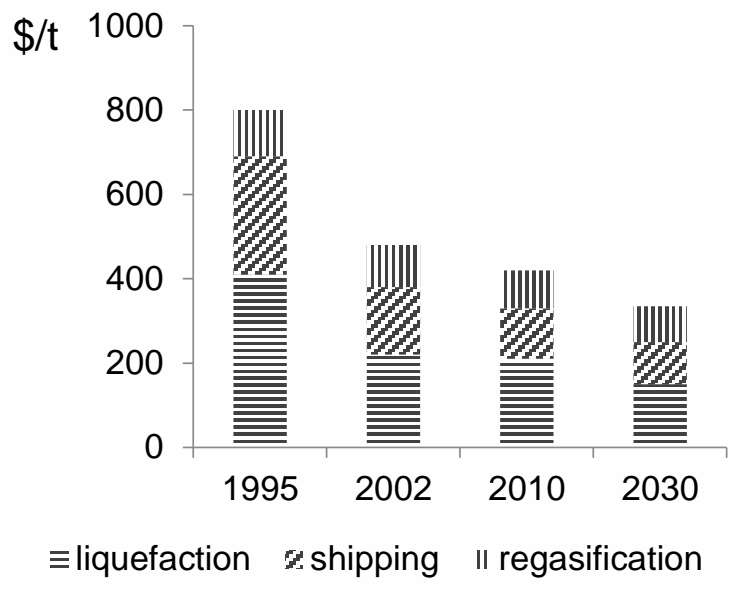

Fig. 1. Capital costs for LNG technology

\section{The main consumers and suppliers of LNG}

In the 1960s and 1970s, LNG was supplied mainly to the Atlantic market - to countries in Europe and the USA, but beginning in the 1970s and 1980s, the emphasis shifted towards the Pacific market. Japan became the first LNG importing country in the Asia-Pacific region (APR), which, in an effort to reduce dependence on oil supplies from the Middle East, established regular LNG supplies from Indonesia.

In the mid-80s and early 90s, South Korea and Taiwan started importing LNG, in 2004, India became one of the Asian importers of LNG, in 2006 - China, which began importing LNG from Australia.

LNG exporters in 2016, bln. M3

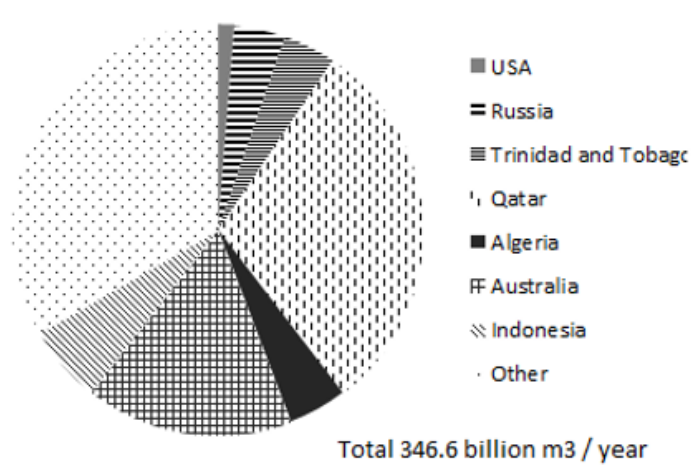

Currently, about $70 \%$ of the world's LNG volumes are shipped to the Asia-Pacific region, which will continue to dominate the future as an importer of gas. Experts predict that China, India, Pakistan, Vietnam, Indonesia, Malaysia and Thailand will be the main "points of growth" in consumption.

In Europe, in recent years, there has been a slowdown in the growth in demand for natural gas, and there is a noticeable tendency to increase the specific weight of LNG in gas imports. The fact that the European LNG market will gain momentum is indicated by the rapid growth of regasification capacities in the region, which have already reached half of the pipeline capacity for gas imports and continue to grow despite the low level of loading. In the future, experts believe, when choosing between pipeline and LNG deliveries, European countries will often opt for the latter. According to the forecast [6], the demand for LNG in Europe by 2030 will grow from the current 47 million to 150 million tons

In the United States, the recent "shale revolution" radically changed the situation in the country. An increase in domestic gas production by $30 \%$ led to its excess in the domestic market, and the States ceased to need imported LNG volumes.

Currently, the USA and Canada, where shale deposits are also being actively developed, are preparing to become major world exporters of LNG, their extracting companies are investing heavily in the conversion of receiving terminals into export and construction of industrial and transport infrastructure.

In 2016, the following structure of LNG exporters was formed and the next demand for LNG is forecasted for the future (Fig. 2).

\section{Demand for LNG in the world, billion $\mathrm{m} 3$}

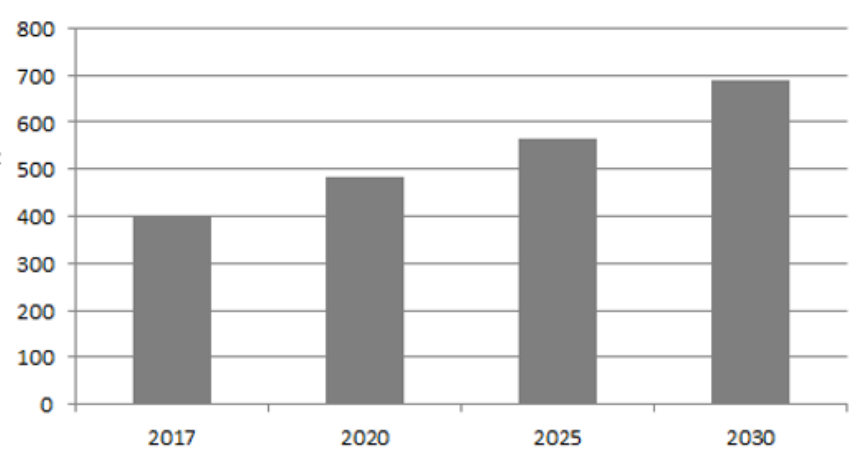

Fig 2. LNG exporters and prospects for LNG demand in the world [7].

At present, the main consumers of natural gas in the Asia-Pacific region are Japan, the Republic of Korea, China and India. With insignificant natural gas resources, the gas supply to the economy of Japan, as to South Korea, is based on imports of liquefied natural gas (Figure3). 


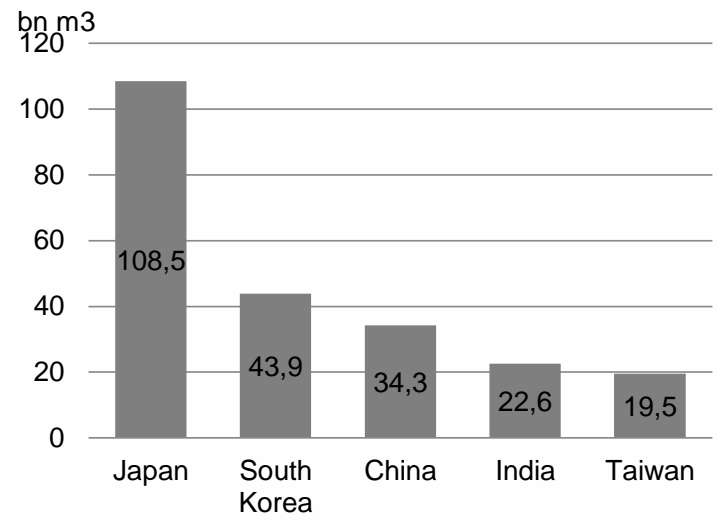

Fig. 3. Largest importers of LNG (2016 г.) [5]

The main exporters are Qatar, Australia, Malaysia, Nigeria and Indonesia (Figure 4).

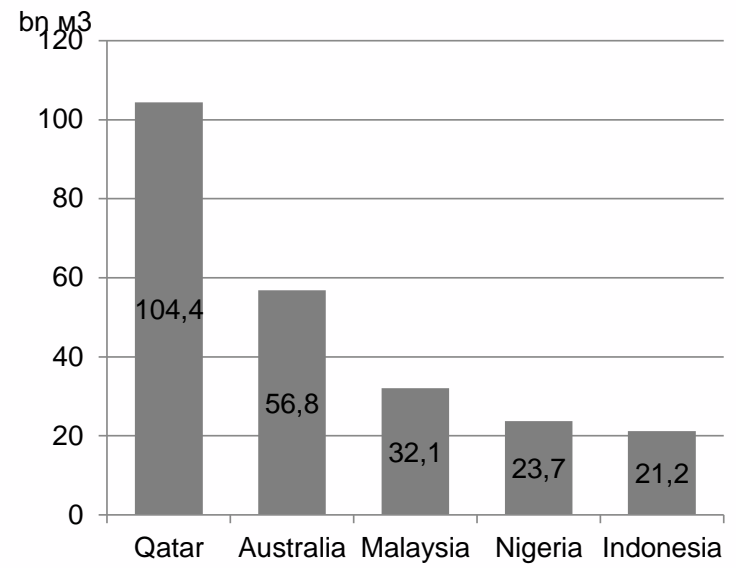

Fig. 4. The largest LNG exporters (2016 г.) [5]

\section{Forecasts of growth in LNG production and Russia's capabilities}

In the long term, from 2016 to 2040, the import of natural gas in the form of LNG will increase according to one of the IEA scenarios around the world (Fig. 5).

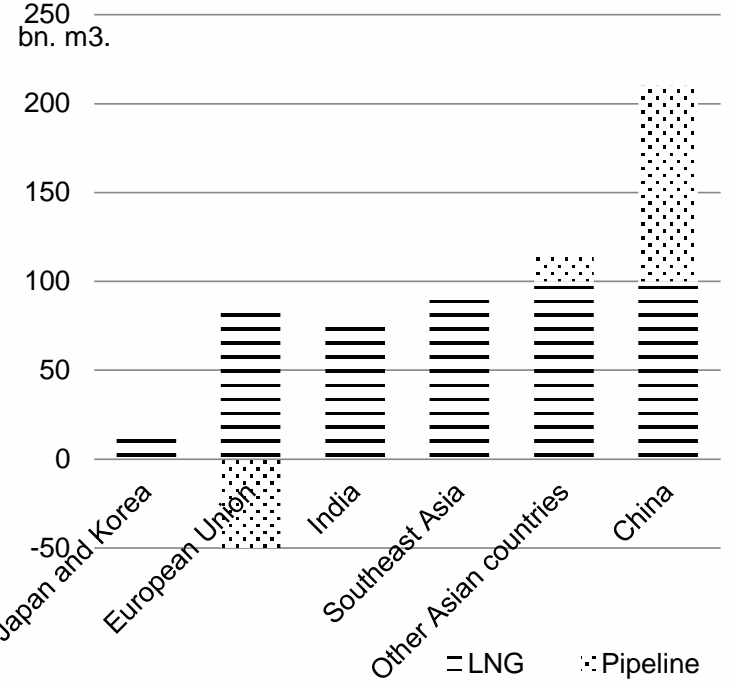

Fig. 5. Change in gas imports by countries of the world, billion $\mathrm{m} 3$ / year [8].

Russia should be interested in diversifying its gas consumers and delivery means. To do this, there is every opportunity: liquefied natural gas from the Yamal fields and from the shelf of the western part of the Arctic seas is convenient to supply to Northern Europe, and the gas reserves of the shelf of Eastern Siberia and the island of Sakhalin to consumers of the rapidly developing Asian LNG market. To strengthen Russia's position in the gas markets of the world, it is important to realize this potential.

The first plant for large-tonnage liquefaction of natural gas in Russia appeared in 2009 as part of the Sakhalin-2 project, which operates under the terms of the Production Sharing Agreement. Its initial capacity was 9.6 million tons per year (two lines in 4.8 million tons), after modernization of production capacity their capacity increased to 10.8 million tons.

The second project began work only after 8 years. In December 2013, the final investment decision was accepted for the Yamal LNG project, and in December 2017 the first line of the plant with a capacity of 5.5 million tons was launched (Table 2). Thus, at the moment Russian capacity is 16.3 million tons.

Table 2. The main Russian LNG projects (large-capacity production) $[9,10]$

\begin{tabular}{|l|l|l|l|l|}
\hline Plant & $\begin{array}{l}\text { Capacity, } \\
\text { million tons / year }\end{array}$ & $\begin{array}{l}\text { Year } \\
\text { launching }\end{array}$ & Status & Shareholders \\
\hline Sakhalin-2 T1, T2 & $\begin{array}{l}10,8 \\
\text { modernization) }\end{array}$ & 2009 & Action. & $\begin{array}{l}\text { Gazprom (50\%), Shell (27,5\%), Mitsui } \\
(12,5 \%), \text { Mitsubishi (10\%) }\end{array}$ \\
\hline Sakhalin-2 T3 & 5,4 & After 2023 & Project & $\begin{array}{l}\text { Gazprom» (50\%), Shell (27,5\%), Mitsui } \\
(12,5 \%), \text { Mitsubishi (10\%) }\end{array}$ \\
\hline Yamal LNG T1 & 5,5 & 2017 & Action. & $\begin{array}{l}\text { «Novatek» (50,1\%), «Total» (20\%), CNPC } \\
(20 \%), \text { Silk Road Foundation (9,9\%) }\end{array}$ \\
\hline Yamal LNG T2, T3+ T4 & $5,5 * 2+0,9$ & 2018,2019 & $\begin{array}{l}\text { Under } \\
\text { construction }\end{array}$ & $\begin{array}{l}\text { «Novatek» (50,1\%), «Total» (20\%), CNPC } \\
(20 \%), \text { Silk Road Foundation и }(9,9 \%)\end{array}$ \\
\hline Arctic LNG-2 T1-T3 & $6,6 * 3$ & After 2023 & Project & «Novatek» and partners \\
\hline Baltic LNG & 10 & After 2023 & Project & «Gazprom», Shell \\
\hline Far East. LNG & 5 & After 2030 & Project & «Rosneft», ExxonMobil \\
\hline Pechora LNG & $<10$ & After 2030 & Project & «Rosneft», «Alltek» \\
\hline
\end{tabular}


After the launch of the second, third and fourth Yamal LNG lines under construction (approximately, by the end of 2019), the total capacity of Russian largetonnage LNG production will reach 28.2 mil-lion tons, which is already comparable to the existing capacities in Malaysia or Indonesia.

However, further plans of companies to expand capacity are associated with great uncertainties. Gazprom has plans for two large-scale projects: within the framework of Sakhalin-2, the expansion of the project is being discussed for many years due to the construction of a third line with a capacity of 5.4 million tons. This production has the lowest prime cost among the new LNG plants in Russia. However, the unresolved problem with the resource base hinders implementation with this project. In addition, the project "Baltic LNG", which assumes gas from the Unified Gas Supply System as a source of gas, is being discussed.

NK Rosneft has plans for the construction of its own LNG production (Far Eastern LNG), but un-der current price conditions its implementation seems unlikely: it is a relatively small (5 million tonnes) greenfield project, which makes the LNG cost is very high. The company is also considering the Pechora LNG project on the basis of the Kumzhinsky and Korovinskoye fields, while certainties for this project are just as few.

Among the most likely new productions - the project "Arctic LNG 2" ("Novatek") - three lines of 6.6 million tons with a resource base of the Morning deposit of the Gydan Peninsula.

The project "Arctic LNG 2" involves the construction of an LNG plant not on land but on gravity-type grounds (300 $\mathrm{m}$ in length and $150 \mathrm{~m}$ in width), which is expected to reduce capital costs by $30 \%$. The target cost of a unit of power is in the range of 650-750 dollars per ton. The construction of an LNG plant on platforms will allow to reduce logistics costs and install the main equipment "remotely" - LNG lines will be built at the Center for Large-Scale Marine Construction in Murmansk.

Moreover, based on the existing resource base on the Yamal and Gydan Peninsulas, "Novatek" is considering the possibility of implementing the projects "Arctic LNG 1 " and "Arctic LNG 3", also for 19.8 million tons each, which implies an increase of the total capacity of the company's factories in the region up to 76.8 million tons (taking into account the construction and operating facilities), which is comparable to the existing capacities of Qatar. But it is clear that it takes to make a long way to realize these ambitious plans.

Based on the current situation and statements of company representatives, the possible total LNG capacity in Russia by the beginning of the 2030s. can be estimated at 60-80 million tons (Figure 6). Some of the more complex projects may not be realized, and new, yet unannounced productions (first of all, in the context of monetization of the gas reserves of "Novatek" on Yamal and Gydan Peninsulas) is possible.

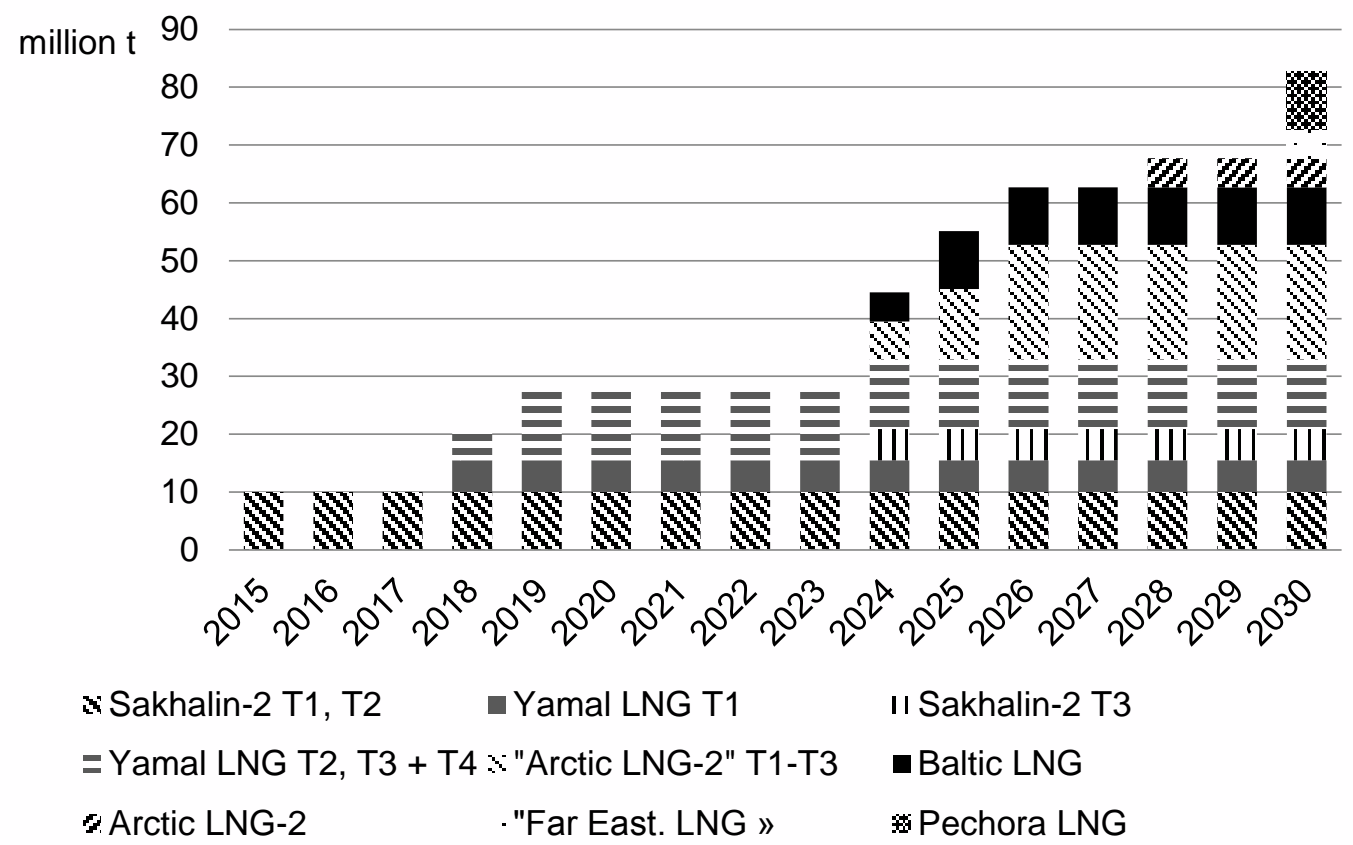

Fig. 6. Possible dynamics of capacity for large-capacity liquefaction in Russia [9]

\section{Conclusion}

The emergence of new Russian LNG projects on world markets occurs in a difficult price environment. In [9] it is shown that Russian LNG occupies an average position among competitors. Estimating the full cost of production and delivery to North-West Europe and
China in the perspective of 2025 shows that Russian LNG is not a closing supplier: new Australian projects and US projects have higher costs $[9,10]$. The unit costs at the Yamal-LNG plant for deliveries to the APR countries are more than $30 \%$ less than the Australian ones and $10 \%$ cheaper than the American projects. Projects Sakhalin-2 cheaper in a similar situation is cheaper than more than 2 times. 
In favor of Russia, such factors as the availability of large gas resources with a fairly low cost, the de-veloped transportation infrastructure, proximity to potential markets (to European and Asian) are acting.

It is possible to develop low-tonnage LNG production, which can be used in difficult situations on transit export corridors, as well as when demand for Russian gas is reduced by external consumers.

According to all forecasts, the world market of LNG will grow rapidly in the nearest decades. But Russia's slow entry into the LNG market can take place in a tough competition. In addition, the biggest negative factor in the implementation of LNG projects in Russia will be the main threat to energy security - a shortage of investments. When all possibilities are realized, the share of Russian LNG by 2030 may account for about 10-15\% of the world trade in liquefied natural gas.

\section{References}

1. N.I.Pyatkova, M.B.Cheltsov, Perspectives of energetic, 7, 8 (2003)

2. BP Statistical Review of World Energy June 2001.

3. BP Statistical Review of World Energy June 2011.

4. BP Statistical Review of World Energy June 2016.

5. BP Statistical Review of World Energy June 2017.

6. http://www.morvesti.ru/tems/detail.php?ID=53333

7. A.Toporkov, Vedomosti, 14.02.2018

8. World Energy Outlook-2017

9. Transforming global LNG market: how Russia cannot lose the window of opportunity/ Energy Center LNA SKOLKOVO. 2018, 59 p.

10. A.Sobko, Oil and gas vertical, 11, 7 (2018). 